\title{
IN SEARCH OF A NEW SYMPOIESIS: A REVIEW OF HIGHER EDUCATION ADMISSIONS IN UZBEKISTAN
}

\author{
Aleksey Semyonov ${ }^{1}$ \\ TEAM University, Uzbekistan
}

\begin{abstract}
Current comprehensive changes in the field of higher education in Uzbekistan have a potential impact on the overall enrollment in higher education (PP-4359, 2019). Rigid admission quotas in Uzbekistan are slowly conceding to a more market-based admissions and student recruitment to support reforms implementation. Cursory glance at the reforms fails to explain unprecedented growth of application numbers to higher education in 2019/20 (PP4359, 2019; "STC comments on the delay of test results publication", 2019) or conjecture about future application patterns. Research presented in this paper aims to investigate the trends in higher education admissions in Uzbekistan through document analysis. It further draws on the effects of the government policy and legislation changes on the admission numbers in Uzbekistan and attempts to shed light on the future dynamics of student recruitment in higher education. The findings suggest that profound all-encompassing reforms in Uzbekistan have, firstly, precipitously increased relevant-age application numbers for 2019/20 academic year, but analysis suggests that this trend is unlikely to continue in the future.
\end{abstract}

Keywords: admissions 2019, Uzbekistan, higher education, educational reforms

\section{Introduction}

Uzbekistan has embarked on a path of new reforms since 2016. Direction of development has reverted from building an inward looking protectionism based economy supported by autocratic self-contained systems to an open market based economy. The process of change required government structures to reshape and find ways to work in a changeable environment.

\footnotetext{
${ }^{1}$ Correspondence: 146 Temur Malik Street, Tashkent, Uzbekistan; Email: asemyonov@,teamuni.uz
} 
Prior to the reforms, the system of education was characterized by heavy centralized control over admission quotas, educational standards, curriculum, program and other major components. The Ministry of Higher and Secondary Specialized Education (MHSSE) had clearly defined boundaries and responsibilities with rigid outlines for interactions with other state bodies. Finally, the system of education acted as a homeostatic cell attempting to regulate internal conditions with little or no consideration of outer environmental influences. Varela et. al (1974) termed systems of these type as autopoietic, i.e. system capable of reproducing and maintaining itself.

The current reforms in Uzbekistan have pushed decision makers to reconsider their raison d'etre and look for a new meaning of their role in a wider state, regional and world context. External factors and interactions with other government and non-government bodies have become a major part of the MHSSE reformed vision. In other words the approach turned from homeostatic to homeorhetic, as opposed to self-management to maintain the balance the MHSSE started to reshape itself making sure that they keep up with the development strategy of Uzbekistan, constantly update their systems and approaches to maintain the development trajectory. Their responses to challenges became adaptive and evolutionary. In other words the system has embarked on a journey from being autopoietic to being sympoietic (Dempster, 2000). Sympoietic systems are "collectively-producing systems that do not have self-defined temporal or spatial boundaries" (Dempster, 1998).

Although both terms autopoietic and sympoietic originate in biological sciences, they are being frequently applied to other human built systems (Danilovic \& Winroth, 2006; Leleur, 2007). The transformations happening in Uzbekistan seem to indicate the attempt to create a sympoietic balance for governance of the system of education. The transition from autopietic to sympoietic state of the system of higher education is clearly far from being accomplished, but the process itself has already resulted in changes in legislation, publishing open data, working with foreign counterparts, restructuring of the governing bodies, interacting with stakeholders, as well as approaches to student recruitment and admission, curriculum development, and setting of the admission quotas. This paper looks into the effect of the changes undergone by the higher education and public education systems to this date on reaching the government goal of improving access to higher education in Uzbekistan.

\section{Literature Review}

Although Uzbekistan has a long-lasting tradition of higher education (Hasanovich, 2016), it has majorly inherited its extant system from the Soviet Union in 1991. Tight government control over the system of higher education had a number of benefits (Bray, 1999), but did not allow any other forms of higher educational institutions (HEI), rather than state controlled to operate (Johnson, 2008). After gaining independence, Uzbekistan as a young state required profound changes in the education system to take place (Lipovsky, 1996, p. 221). The reforms in higher education (HE) and vocational education and training (VET) took place in accordance with the law "On Education" ("Ob Obrazovanii", 1997) and "National Program on Personnel Training" ("Nacional'naja programma po podgotovke kadrov”,1997) both being current in 2019. The National Program on Personnel Training is a strategic document. It aims at implementation of the reforms in three phases. The first phase being implemented in 1997-2001 laid the legal, personnel, scientific-methodological and financial basis for reforming and developing the education system. It laid the foundation for the new system of continuous education, including establishment of professional colleges and academic lyceums, and formation of two-tier system of HE. The second phase, implemented in 2001-2005, aimed at improvement of the quality of education and training of teachers. 
Final, third phase, implemented since 2005 targeted increase in international cooperation for the achievement of the goals of the program.

The reforms in education did not focus on increasing admission numbers in higher education. As a result, Uzbekistan's gross tertiary enrolment rate declined from 17 percent in 1991 to 9 percent in 2011 and remains low by regional and international standards (World Bank, 2014). Considering the fact that in 1991 access to higher education was the lowest among the other 15 Soviet republics (Ruziev \& Burkhanov, 2016), the situation with admissions and access to higher education at the regional level has deteriorated even further. Uzbekistan has had major reforms since gaining independence in 1991 to ensure development and economic growth. The reforms in education initiated in the 1990 curbed the education system to produce qualified professionals for the labor market in the country with little attention to wide-ranging human development. However, research shows that it is the human development focus primacy - not the economic growth, which yields in sustainable results (Ranis, Stewart, \& Ramirez, 2000). Ranis et. al. argue that countries initially favoring economic growth lapse into the vicious category, while those with good human development and poor economic growth sometimes move into the virtuous category. This is further buttressed by the findings that the number of years of schooling positively affects the economy on both micro and macro levels (Krueger \& Lindahl, 2001). Thus, allowing population to continue their post-secondary education facilitates development in the long term.

Furthermore, a study conducted in India to investigate the relationship between economic growth and education has found that it is female education at all levels that has the potential to affect the economic growth (Self \& Grabowsky, 2004). In Uzbekistan, despite the increase of absolute numbers of enrolment to tertiary education since independence, the relative numbers were dropping. The relative numbers for female enrolment were dropping even faster. According to the World Bank report (World Bank, 2014) in 2000 the percentage of females among HE students were $45.1 \%$, while in 2011 it was only $38.6 \%$.

At the same time, Aghion et.al reports on findings that investments in "highbrow" education (e.g. higher education) are substantially more growth enhancing for the states closer to the technological frontier, while investments in "lowbrow" (e.g. secondary) education are substantially more growth enhancing for the states further from the technological frontier (Aghion, Boustan, Hoxby, \& Vandenbussche, 2005). Considering the situation of Uzbekistan in 1990 - being the state further away from the technological frontier - this research provides support for the enacted reforms.

Uzbekistan, unlike many other countries of the former Soviet Union (Smolentseva, Huisman \& Froumin, 2018), provided strong support to the development of national vocational education and training system through the reforms in the 1990s. Research by Nilsson (2010) indicates, however, that there is little evidence to suggest a relationship between vocational education access and economic growth. If the choice lies between the two systems HE and VET and their impact on the economic growth, then the latter does seem to have a stronger impact (Vu, Hammes, \& Im, 2012). The reversed effect of economic growth on vocational education seems to be stronger than on university education, however considering the centralized top-down approach to reforms in Uzbekistan additional research is needed to confirm the applicability of this finding to the local context. In Uzbekistan the reforms concentrated on moving the majority of 9-year school graduates to vocational colleges - around $90 \%$ of students, and a small proportion of those to the academic lyceums - around 10\% (Helbich et. al., 2019). When the choice resides between vocational or general education, researchers find various balance levels to be appropriate. 
Examining the difference between policies in Europe and the US, Krueger \& Kumar (2004) found that European education policies oriented toward specialized, vocational education have positively affected growth rates and welfare during the 1960s and 1970s when available technologies changed slowly. However, in the 1980 s and 1990 s when technological changes accelerated, those policies might have contributed to a wider growth gap relative to the United States. Authors explain that vocational enrollment rates at the upper secondary level and beyond are much higher in Europe, while the net entry rate into universities, where general education is primarily imparted, is more than twice the rates of most European countries. Thus this research indicates that strong impact of vocational education on economic growth might not occur in the modern times.

Nonetheless, vocational and/or general education does not preclude access to higher education. In fact, in some countries, vocational education increases the opportunities to enter higher education (Moodie \& Wheelahan, 2009). This situation is witnessed in countries with high availability of higher educational opportunities. Vocational education as well as general education allow increasing the overall level of education among the population and help applicants to meet the universities' minimum admission requirements. In Uzbekistan, due to the presence of rigid quotas for admission in higher education as well as rapid population growth the demand for higher education constantly increased, while the offer remained relatively constant (see Table 1). This coupled with the fact that vocational education and general education were compulsory, i.e. the potential advantage was given to the entire population of the relevant age group, did not give graduates a boost up while attempting to secure a place in an HEI.

Currently the government of Uzbekistan is on a pathway of profound reforms including reforms in education. One of the goals is to increase enrolment of students in higher education by making it more accessible and available. In recent years the number of HEIs has been increasing, thus making HE more available. At the same time starting from 2019/20, the government started to remove rigid admission quotas attempting to make HE more accessible (PP-4359, 2019). Considering the reforms and their implementation the aim of this paper is to analyze the current state of recruitment in higher education and sustainability of the current trend.

\section{Methods}

Document analysis and review of the media sources is the primary methodology adopted in this study. While government acts, official interviews, and presidential speeches are analyzed in order to draw information of the direction of the reforms in Uzbekistan, media coverage of the admission campaigns, press conferences with the state officials responsible for admissions, video coverage of the admission process, independent journalist investigations and comments are reviewed to create an overview of their actual implementation.

The media sources were chosen based on their popularity and language (Uzbek and Russian language media):

- Kun.uz and Daryo.uz news agencies - popular Uzbek language media resource in Uzbekistan with more than 12 million and 6 million visitors respectively as of August 2019.

- Gazeta.uz - popular Russian language media resource with more than 2 million visitors in August 2019. 
- Podrobno.uz and nuz.uz - popular Russian language news agencies with more than 1 million visitors in August 2019 each (SimilarWeb, 2019).

The state media resources uza.uz and uz24.uz were only reviewed to triangulate the information presented in other media sources due to their comparatively low popularity: uza.uz - 419 thousand visits and uz24.uz - 122 thousand visits in August 2019. Similarly, news agencies websites operating outside of Uzbekistan, namely ozodlik.org (838 thousand viewers in August 2019) were reviewed for triangulation purposes. Interviews of the officials are referenced from available media sources. Finally, news published on the official university, ministry, government websites were considered.

Official government released statistics, numbers reported by the government officials in the course of press conferences and interviews are analyzed for the purposes of identifying trends in admission patterns. Interview data is compared to the goals set in the government documents related to the admission campaign of 2019. Legislation acts are accessed from two official repositories of the legislation of Uzbekistan: lex.uz and nrm.uz.

Overall 16 acts of legislation, 11 official ministerial press conferences (including 7 official statements of intent), 3 independent education system review reports, 4 independent journalists' investigations, and 3 official statistics sources - all pertinent to the admission 2019/20 were reviewed.

Conclusions are drawn on the basis of the conducted analysis.

\section{Background information}

Both HE and VET are managed and administered by the Ministry of Higher and Secondary Special Education (MHSSE) of the Republic of Uzbekistan established on January 7, 1990. Major changes in the operation of MHSSE were introduced by the enactment of the Resolution of the Cabinet of Ministers of the Republic of Uzbekistan "Concerning the Activity Modernization of The Ministry of Higher and Secondary Specialized Education of the Republic of Uzbekistan" (2004), and further by the Presidential Decree "On measures of cardinal improvement of the systems of general secondary, secondary specialized and professional education" (2018).

Admission quotas to HEI and VET educational establishments (with the exception of some internationally affiliated HEIs) are regulated by the Presidential Decrees issued annually. The figures for admission to HE from 2011/12 to 2019/20 academic years are provided in Table 1.

The numbers are drawn from the individual course/program specific quotas, which are determined in consultation with the stakeholders. Thus, each HEI operates quotas for individual programs of study. Applicants, except for those exempt by the official government acts, are required to sit the entrance examinations administered by the State Testing Centre (STC) - organization responsible for preparation, monitoring and verification of testing questions and results. Students are admitted to universities in accordance with the quotas and results of the examination. This system is in place for HEI since 1994 and in VET since 1995 (Helbich et. al., 2019).

The number of vocational colleges and academic lyceums in Uzbekistan has grown rapidly, from under 50 in 1998 to over 1,500 in 2014 (Helbich et. al., 2019). Until 2018 the secondary VET education was coordinated by the Centre for Secondary Specialized Vocational Education under the Ministry of Higher and Secondary Specialized Education, after 2018 by the Centre for Professional Education under the Ministry of Higher and Secondary Specialized Education. Both the government and international partners have made significant investments in infrastructure in recent years, particularly in the secondary 
specialized education sector, to enhance the quality of vocational training (Helbich et. al., 2019).

Table 1.

Figures on admission to HEI

\begin{tabular}{lccl}
\hline & $\begin{array}{c}\text { Number of } \\
\text { students to be } \\
\text { admitted to } \\
\text { Bachelor's } \\
\text { degree studies }\end{array}$ & $\begin{array}{c}\text { Number of } \\
\text { students to be } \\
\text { admitted to } \\
\text { Master's } \\
\text { degree studies }\end{array}$ & \multicolumn{1}{c}{ Reference } \\
\hline $\mathbf{2 0 1 9 / 2 0 2 0}$ & 80430 & 7695 & Presidential Decree (PP-4359), 2019 \\
$\mathbf{2 0 1 8 / 2 0 1 9}$ & 69200 & 5903 & Presidential Decree (PP-3769), 2018 \\
$\mathbf{2 0 1 7 / 2 0 1 8}$ & 66316 & 5000 & Presidential Decree (PP-2955), 2017 \\
$\mathbf{2 0 1 6 / 2 0 1 7}$ & 57907 & 5000 & Presidential Decree (PP-2534), 2016 \\
$\mathbf{2 0 1 5 / 2 0 1 6}$ & 57907 & 5000 & Presidential Decree (PP-2359), 2015 \\
$\mathbf{2 0 1 4 / 2 0 1 5}$ & 57907 & 5000 & Presidential Decree (PP-2 193), 2014 \\
$\mathbf{2 0 1 3 / 2 0 1 4}$ & 56607 & 6300 & Presidential Decree (PP-1982), 2013 \\
$\mathbf{2 0 1 2 / 2 0 1 3}$ & 56607 & 6300 & Presidential Decree (PP-1751), 2012 \\
$\mathbf{2 0 1 1 / 2 0 1 2}$ & 56607 & 5880 & Presidential Decree (PP-1564), 2012 \\
\hline
\end{tabular}

\section{Current Changes}

Changes in higher education environment in Uzbekistan have gained momentum in the recent years. Number of higher education providers as well as their profiles are rapidly changing. Within a short period of time the number of officially reported higher education establishments in Uzbekistan has increased from 96 (March, 2019) to 113 (September, 2019) see Figure 1. There are 113 higher education institutions out of which 25 are Universities, 33 are Institutes, 2 Academies, 30 branches of HEI, 1 Conservatory, 1 Highest school, and 21 affiliations of foreign institutions (MHSSE, 2019) as of September 2019.

HEIs report to the Ministry of Higher and Secondary Specialized Education (MHSSE), as well as, in the case of specialized institutions to the other sectorial ministries, e.g. Ministry of Justice for the University of Law ("Higher education in Uzbekistan", n.d.). Although foreign HEI were present in Uzbekistan from early 2000 s in the light of the current reforms in education the government is opening educational market to foreign providers. One of the pioneers in exploring this new opportunity is Webster University, which has launched a program on the basis of Tashkent University of World languages in 2018 ("TESL in Uzbekistan”, 2018). The other providers include the Northern Consortium of UK universities (NCUK) with admission to its foundation programs, Amity University with plans to open campus in Uzbekistan in 2019-2020 and others. Moreover five major universities of the Russian Federation, namely Moscow Institute of Steel and Alloys, Bauman Moscow State Technical University, Sechenov First Moscow State Medical University, Moscow Architectural University, Russian Technological University, have announced intentions to 
open affiliated branches in Uzbekistan ("Pjat' krupnyh rossijskih", 2018). Overall, the President of the Republic of Uzbekistan in his address to the nation in September 2019 has pointed out that in the last two years 35 universities, including 13 in partnership with foreign countries, have opened in Uzbekistan (Mirziyoev, 2019).

\section{Figure 1.}

Changes in the Numbers of Higher Education Providers, March-September 2019

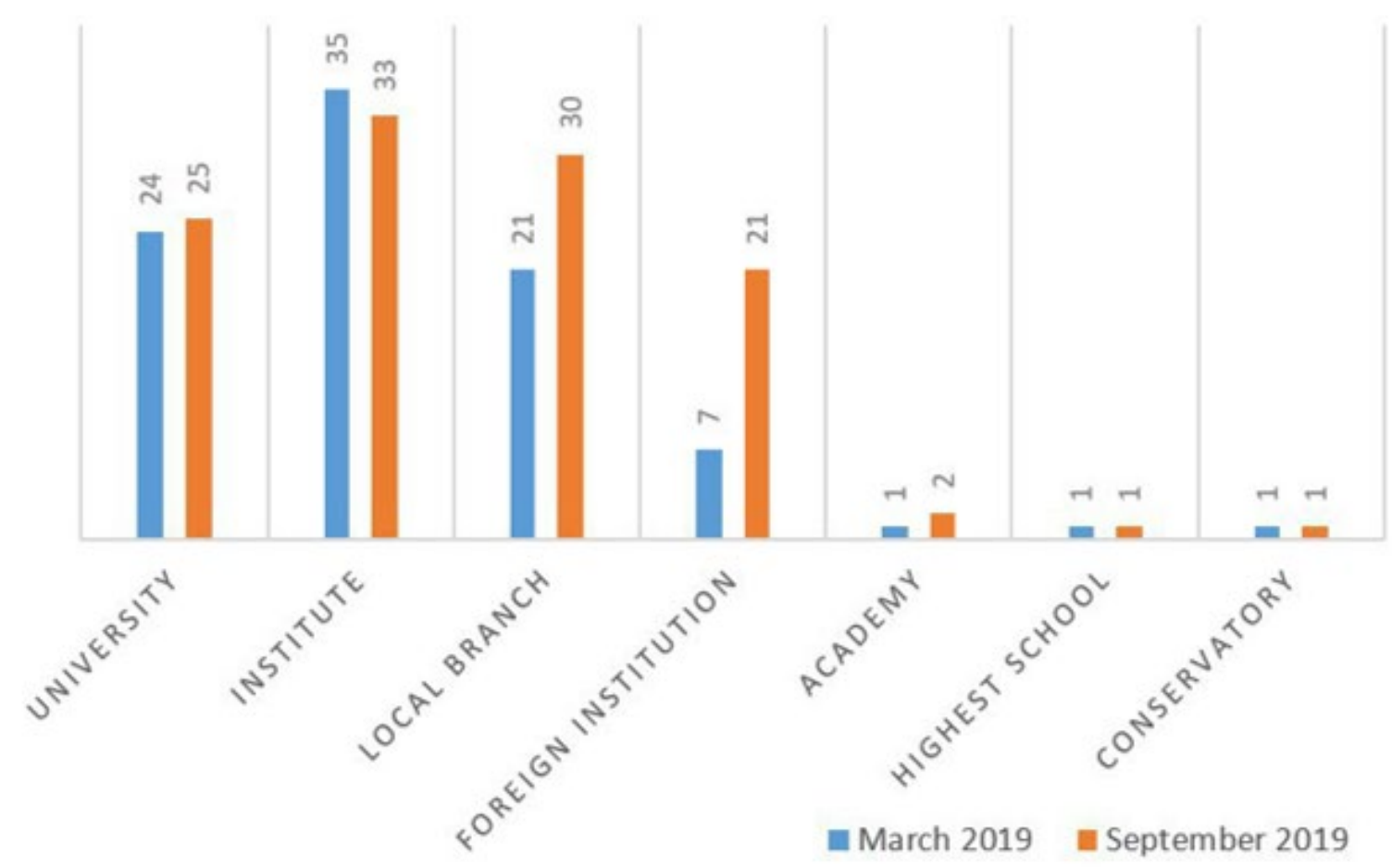

A considerable transformation launched in 2016 was full modernization of bachelor and masters curricula considering the best practices of successful universities of the world. The modernization proposes new requirements for teaching staff and study programs, which are revised and updated taking into account changing labor market requirements ("Higher education in Uzbekistan”, n.d.). This reform considers sustainability issues and programs are being reviewed on a yearly basis. More than 100 bachelor and 94 master's programs were opened in the past years (Mirziyoev, 2019). These changes increase the range of higher education options for prospective students and aim at increasing availability as well as enrolment in higher education.

Since 2016 vocational education and training system was also going through major reforms. Together with the system of public education, the transition between secondary and secondary specialized education has been reviewed in order to provide opportunities for students to choose between school/lyceum as opposed to lyceum/college after completion of the first 9 years of schooling starting from 2017/18 academic year. In 2018 a Decree of the President of the Republic of Uzbekistan "On measures for cardinal improvement of the general secondary, secondary specialized and professional education” (2018) has been adopted. There are two major changes provided for in the decree. The first one is that from the 2018/19 school year, compulsory general secondary and specialized secondary education is carried out in 
general education schools, including boarding schools, specialized schools, and academic lyceums on the basis of continuous and 11 years cycle. The second change is that starting from the 2019/20 school year, admission to vocational colleges will be carried out from among graduates of 11 th grade of general education schools on a voluntary basis in order to obtain the relevant specialty (profession) with a term of study from six months to two years. In 2018 Centre for Vocational Education has been created to replace the Centre for Secondary Specialized Vocational Education in order to further enhance the quality of vocational education in the country and support implementation of the decree.

The admission quotas have not been showing considerable growth from 2011 to 2016 and have only began to increase since 2016 (see Table 1) with a major increase in bachelor $(16.2 \%)$ and masters (30.4\%) quotas for 2019/20 as compared to 2018/19. The major change in 2019/20 admissions compared to previous years is that of allocation of additional quotas. Prior to 2019/20 the admission quotas were informed by labor market research outcomes, while in 2019/20 the quota is formed from the state order (by the major industries) as well as by the HEIs themselves. The latter allows HEIs in consultation with their corresponding ministries/stakeholders and based on their capacity to admit more students to both bachelor and master's programs. HEIs affiliated with foreign partners set their own quotas/targets for admission. Coverage of population with higher education has increased from $9 \%$ to $20 \%$ in the last two years and is targeted to be increased to $25 \%$ in the nearest future (Mirziyoev, 2019).

Despite that, due to the aforementioned reforms in public education in 2019/20 academic year Uzbekistan has seen a spike of application numbers, which increased competition for admission in HE. The majority of students in 2016/17 have been left in 11year schools, rather than being distributed in 12 - year vocational colleges and lyceums. At the same time those students who entered vocational colleges and lyceums in $2015 / 16$, i.e. nearly all school leavers for that year, were to finish their 12-year programs in 2018/19. Thus, for 2019/20 academic year the number of applications to higher education, according to the STC, was 1,066,925, which is 250,000 more as compared to 2018/19 ("DTM test natijalari", 2019). This statement, although officially made by the STC, does require further clarifications as in media coverage of previous (2018/19) year admission indicated that 675 , OOO students have submitted documents in 2018 (Isaev, 2018) making discrepancies between the numbers too large to ignore. Taking into account increased quotas, again only about $10 \%$ of the applicants have been successful in securing their place in HEI in 2019/20. The number comparable to that in 2018/19, considering the increased number of applicants and the increased quotas for $2019 / 20$.

This fact indicates that despite attempts to boost enrolment in higher education, in 2019/20 both applicants and the state faced difficulties in materialization of their aspirations. This conclusion finds further support in the media coverage of the application process in Uzbekistan. The STC, ultimately responsible for preparation of the test and release of the results has faced a number of difficulties. First of all, the administration of the test has changed. Previously all applicants would sit the entrance examinations on the $1^{\text {st }}$ of August of the respective year of admission, while in 2019/20 the tests were distributed and delivered from the $29^{\text {th }}$ of July 2019 through to $15^{\text {th }}$ of August 2019. This change was aimed at reduction of disturbances caused by a single time administration of the entrance exams. However, it created certain challenges for the STC. According to the official decision the STC was set to release the results within a week of the conclusion of the examination process, i.e. on the $22^{\text {nd }}$ of August (PP-4319, 2019). Although in some cases the results were announced on the day of the exam ("Bakalavriat yo'nalishining 6-avgust", 2019), the STC fail short of 
maintaining this pace. Moreover, previously applicants could only apply to a single HEI, but in 2019/20 they were given an opportunity to apply to three institutions simultaneously. Both of the reasons were formally acknowledged by the STC during their press conference for journalists as challenges ("DTM test natijalari", 2019).

Submission of documents and selection of university procedures were also planned to be administered differently to the practices of previous years -all applicants to bachelor programs were to submit documents through the Centers of State Services (PP-4319, 2019). The service was timely launched, but various media sources have been reporting poor organization of the service provision. Queues (Ozodlik Radio, 2019), problems with the electronic systems (“Abiturienty, vuzy i sboj sistemy”, 2019), delays and applicants discontent ("V Navoi", 2019) have all been reported by the media. Although some of the problems were not officially acknowledged by the organizers, video footage from the application submission sites does indicate that the process could have been better planned and administered. The STC has conducted a press conference on lessons learned and shared their views on subsequent changes to be implemented the next year as a reaction to comments discussed in the media ("Davlat test markazi direktori", 2019).

Increased numbers of applicants have positively affected admissions to HEI affiliated with foreign partners. Management Development Institute of Singapore in Tashkent has reported that the number of applications has exceeded the target number (MDIS (Singapore) Counselling Sessions, 2019) and the university have been taking steps to accommodate for the increased demand. Westminster International University in Tashkent (WIUT) has planned for the increased number of applications and has been able to increase the number of admissions to its foundation year program. The WIUT news reported 34 groups of newly admitted students in 2018 (WIUT, 2018) as opposed to 50 new groups in 2019 (WIUT, 2019). Inha university in Tashkent has reported readiness to admit not less than 420 new students in 2019 ("Inha will host at least 420 students in the 2019-2020", 2019) - a number also announced in 2018 (Inha, 2018). Other internationally affiliated HEIs have also been able to benefit from the increased numbers of applications.

\section{Reasons for the increased number of applications to HEIs}

Inflated application numbers can be explained by looking at the system of education holistically. Explanation of the increased numbers for 2019/20 can be found not within the changes in the system of higher education, but through a closer look on the system of public education and its concurrent transformation. The reforms have pulled the systems closer together entwining them even further - a step toward sympoiesis.

In 2017 the government announced that year-9 students are to either remain at schools or transfer their studies to professional colleges or academic lyceums. The majority of parents have decided to leave their children at schools ("V kazhdom rajone stolicy l", 2017) and continue with an 11-year secondary education cycle. At the same time, those students who have already been studying at vocational colleges and lyceums at the time of the change were allowed to continue their 12-year education. Ensuing from this decision in 2019/20 admission period students from two cohorts - those from secondary schools, i.e. 11-year cycle students, and those from vocational colleges and lyceums, i.e. 12-year cycle students, - were applying for a place in higher education.

Therefore, relevant-age (applicants graduating from secondary educational establishments and seeking to enroll to bachelor programs) application numbers observed in 2019/20 are unlikely to be repeated in the subsequent years. Moreover, this change might 
have an effect on the quality of applicants in the next few years due to the challenges faced by the Ministry of Public Education.

\section{Challenges faced by the Ministry of Public Education and the Ministry of Higher and Secondary Specialized Education}

In Uzbekistan professional colleges and academic lyceums are managed by the Ministry of Higher and Secondary Specialized Education (MHSSE), while secondary schools are managed by the Ministry of Public Education (MPE). Prior to 2016/17 academic year, a student would complete a 9-year school and progress to the system of colleges and lyceums, i.e. would progress from an educational establishment managed by the MPE to an establishment managed by the MHSSE. In 2016/17 this process has been interrupted, and the MPE has received additional, unplanned number of students in grade 10, while at the same time the MHSSE has not received previously planned number of students into its college/lyceum system. Considering this MPE has been faced with a number of challenges that need to be addressed in the near future to maintain quality of education. Statistics officially published at the MPE website are presented in Table 2. It is evident from the figures reported that while number of schools shows a modest increase, the numbers of students and teachers are increasing at a much faster pace.

Table 2.

Official Statistics on Schools, Teachers and Students by the MPE ("Key indicators of the Ministry of Public Education”, 2018)

\begin{tabular}{lccc}
\hline & $\mathbf{2 0 1 6 / 1 7}$ & $\mathbf{2 0 1 7 / 1 8}$ & $\mathbf{2 0 1 8 / 1 9}$ \\
Number of Schools & 9657 & 9628 & 9691 \\
Number of Students & 4808058 & 5248484 & 5821861 \\
Number of Teachers & 389740 & 408135 & 444788 \\
Average number of students per school & 497.9 & 545.1 & 600.7 \\
Average number of students per teacher & 12.3 & 12.9 & 13.1 \\
\hline
\end{tabular}

The MPE additionally reports on the schools' capacity. In 2016 the capacity coefficient, i.e. the measure of the number of students vs. school resources, was equal to 1.0. However, in 2018 the coefficient has increased to 1.2 indicating insufficient resourcing. The ministry addresses the challenge by building new schools, hiring more qualified teachers, diversifying investment to the schooling system, supporting private schools' development. However, in the near future, based on the statistics, school students would still be disadvantaged in terms of resources per student in comparison with their counterparts from the previous years. The situation observed might have a negative effect on admissions to higher education not in terms of numbers, but in terms of quality of applicants' education.

Inevitably due to the increased number of students in schools the MHSSE faces a converse problem. Based on the presidential decree students would further be admitted to professional colleges after 11-year school cycle (PP-5313, 2018). This decision has created a transition period issue in 2017/18 as colleges would under recruit new students due to the fact that students (or their parents on behalf of the students) would simply make a decision to stay at school.

Moreover, it created a balance issue for the MHSSE as colleges start to compete for students with HEI. Previously students would choose to go to the HEI after graduation from their college/lyceum. Since after implementation of the changes graduates of colleges would still be able to enter higher education it is unclear how much the change is going to affect 
quality of students who wish to study in a college or in a HEI. The reforms envisage more resourcing for colleges, better teaching staff and updated standards to make vocational education attractive to students. However, for the true sympoietic implementation of the changes, other stakeholders and reforms in other areas should also be taken into consideration.

The MHSSE additionally faces challenges related to sustaining the property of colleges and lyceums. In 2018 the media reported the official response to the concern that many buildings occupied by colleges would become unused. The officials have assured that changes in the system of education do not necessarily mean closing down colleges ("Kakoe budushhee zhdet kolledzhi”, 2018). However in September 2019, the decree of the President of Uzbekistan have officially reallocated 30 colleges to the Ministry of Labor for creation of centers of professional education, 69 colleges have been passed to the HEI to strengthen their capacity, 97 colleges to HEIs for establishment of multi-profile learning centers and practical internship centers, 388 colleges were passed to MPE for reorganization into schools (PP5812, 2019). As of 2012 there were 1396 professional colleges (Tashpulatov, 2012). Every year a number of colleges would be reorganized, but normally colleges would remain within the system of MHSSE. In 2019, however, 584 colleges were reorganized and/or removed from the system, which is an unprecedented number.

\section{Opportunities and challenges}

Current reforms, development of legislation and changes in admission flows generates a number of opportunities for the local as well as foreign stakeholders.

The transition period of meeting the demand in public education sector creates opportunities for private training centers to attract students to their courses. Concerns that overpopulated schools are struggling to keep the quality and standards push parents to seek additional means for educating their children - private tutoring, education and training centers, professional and preparatory courses. These measures alleviate the problem of the quality of education, but at the same time create challenges for the government in terms of quality assurance of the study programs. Private centers are often seeking to employ innovative methodologies to facilitate marketing of their offerings, while the government is yet to resolve the problem of controlling their novel approaches for quality assurance and licensing purposes.

Current dynamics create opportunities for investors in the system of public education ensuing from the intentions of the MPE to diversify its funding sources (PP-5712, 2019). Establishment of a sympoietic system in education further incites interest in foreign partners to invest and facilitate system development and transformation. The current growth of the foreign establishments' presence on the market of Uzbekistan is an indicator of changing educational climate. Enrollment in higher education in Uzbekistan remains low and projected to remain below $25 \%$ in the next few years by the government of Uzbekistan. Low access to higher education and efforts of the government to increase enrolment rates create ample opportunities for the foreign HEI to create partnerships and establish collaborations in Uzbekistan as, although numbers of relevant-age applicants are unlikely to reach the levels of 2019/20 in the nearest future, they will find a large market with high demand for HE, but limited offer.

Developing legislation stipulates changes in the current standards and programs being delivered. Universities and ministries express full support for the new partnerships development both within and outside the country. Moreover, considering the changing educational climate, programs with English medium of instruction are set to expand (Weitz, 
2018). The ensuing challenge for the government is quality assurance of new programs as well as development of common standards for quality assurance of the programs developed and influenced by partners from a range of countries.

The latter creates opportunities for international students. Uzbekistan does provide a number of programs in the Russian language and starts to expand the portfolio of programs in the English language, which is a pull factor for international students. Considering the cost of living in Uzbekistan as well as tuition being relatively low, the reforms provide financially attractive models for obtaining internationally recognized education. Normally, international students follow somewhat modified procedures of admission due to the challenges associated with sitting the STC administered examinations - an opportunity to be considered outside of standard quotas, which the government is planning to make more flexible.

\section{Conclusions}

The reforms in Uzbekistan are profound and bear consequences for the existing systems in their search of a new sympoietic balance. Reforms in post-primary education in particular seem to affect both the MPE and the MHSSE but create somewhat opposite challenges for both ministries. Sympoiesis of systems allows smoother transition between the levels of education and promises to be less resource intensive for all stakeholders due to collective rather than self-centered, inward looking development. The government drives the current reforms by long-term planning and strategic vision, but these would bear fruit only in the years to come when both the MPE and the MHSSE find their new sympoietic balance. Current research indicates that the changes are dramatic and happen at a pace, which creates challenges for both beneficiaries and benefactors. Moreover, the fact that the officials' statements and subsequent actions do not always converge to the official documents indicates concurrent inconsistencies during tactical and operational decision-making.

Sympoietic influences are visible from the effect of reforms in public education on the numbers of relevant-age applications to the HEIs in 2019/20, but those are found to be unsustainable and are not anticipated in the near future. The numbers are explained by systematic changes and associated transition periods. Some stakeholders have not seized the opportunities created by the increase in application numbers, but internationally affiliated universities and private education providers seem to have benefitted from the change. Next year, 2020/21, the HEI should expect lower number of relevant-age applicants. Although demand for higher education is still below the offer, with saturation of the market universities would need to reconsider their recruitment strategies in order to cope with the growing competition.

Finally, current challenges faced by the MPE in terms of number and conditions of schools might lead to fluctuating quality of applicants, which has to be taken into account by all HEI in order to maintain their admission standards while keep recruitment numbers healthy and sustainable.

\section{References}

Abiturienty, vuzy i sboj sistemy: kak prohodit priem dokumentov v regionah [Applicants, universities and system failure: submission of documents process]. (2019, July 11). Retrieved from https://kun.uz/ru/news/2019/07/11/abituriyenty-vuzy-i-sboysistemy-kak-proxodit-priyem-dokumentov-v-regionax 
Aghion, P., Boustan, L., Hoxby, C., \& Vandenbussche, J. (2005). Exploiting states' mistakes to identify the causal impact of higher education on growth. Retrieved from: https://scholar.harvard.edu/files/aghion/files/exploiting_states_mistakes.pdf

Bakalavriat yo'nalishining 6-avgust kungi test natijalari e'lon qilindi [The results of the bachelor's degree exams from August 6 are announced]. (2019, August 7). Retrieved from https:/ / daryo.uz/2019/08/07/bakalavriat-yonalishining-6-avgust-kungi-testnatijalari-elon-qilindi

Bray, M. (1999). Control of education: Issues and tensions in centralization and decentralization. In R. F. Arnove and C. A. Torres (Eds.), Comparative education: The dialectic of the global and the local (pp. 207-232). Rowan \& Littlefield.

Danilovic, M., \& Winroth, M. (2006). Corporate manufacturing network: from hierarchy to self-organising system. International Journal of Integrated Supply Management, 2(1), 106-131. https://doi.org/10.1504/IJISM.2006.008341

Davlat test markazi direktori: kelgusida testdan oldingi va keyingi jarayonlarni ochiq namoyish etish rejada bor [Director of the State Testing Center: It is planned to openly demonstrate the pre- and post-test procedures]. (2019, July 28). Retrieved from https://daryo.uz/2019/07/28/davlat-test-markazi-direktori-kelgusidatestdan-oldingi-va-keyingi-jarayonlarni-ochiq-namoyish-etish-rejada-bor

Dempster, M. B. L. (1998). A self-organizing systems perspective on planning for sustainability (Unpublished doctoral dissertation). University of Waterloo.

Dempster, B. (2000, July). Sympoietic and autopoietic systems: A new distinction for selforganizing systems. In Proceedings of the World Congress of the Systems Sciences and ISSS (pp. 1-18). Toronto, Canada.

Hasanovich, K. A. (2016). Education system and great sufi in Central Asia XVI century. European Science Review, (7-8), pp 14-16. Retrieved from: http://ppublishing.org/upload/iblock/d8f/ESR_7-8_2016.pdf

Helbich J., Dubecova A., Ulbricova L., \& Semyonov, A. (2019). Central Asia Education Platform II. Summary and update on education systems and policies in Central AsiaUzbekistan. Retrieved from https://www.caep-project.org/wpcontent/uploads/2019/03/CAEP Uzbekistan-HE-and-VET-Brief.pdf

Higher education in Uzbekistan. (n.d.). Retrieved from https://supporthere.org/page/higher-education-uzbekistan

INHA. (2018, May 25). Universitet Inha v g. Tashkente nachal priem dokumentov ot abiturientov [Inha University in Tashkent began accepting documents from applicants]. Retrieved from https://inha.uz/ru/news/589

INHA. (2019, June 7). V 2019-2020 uchebnom godu Universitet Inha v Tashkente primet ne menee 420 studentov [Inha will host at least 420 students in the 2019-2020 academic year]. Retrieved from https://nuz.uz/nauka-i-tehnika/41123-v-20192020-uchebnom-godu-universitet-inha-v-tashkente-primet-ne-menee-420studentov.html

Isaev, T. (2018, July 18). V vuzy Uzbekistana v jetom godu sdali dokumenty 675 tysjach abiturientov [This year, 675 thousand applicants submitted documents to universities in Uzbekistan. Retrieved from https://podrobno.uz/cat/obchestvo/vvuzy-uzbekistana-v-etom-/?sphrase_id=630192

Johnson, M.S. (2008), Historical legacies of soviet higher education and the transformation of higher education systems in post-Soviet Russia and Eurasia. In Baker, D.P. and Wiseman, A.W. (Ed.) The Worldwide Transformation of Higher 
Education (International Perspectives on Education and Society, Vol. 9), pp. 159-176. Emerald Group Publishing Limited.

Kakoe budushhee zhdet kolledzhi Uzbekistana [What future awaits colleges in Uzbekistan]. (2018, February 12). Retrieved from https://stv.uz/news/obshestva/7253-kakoe-buduschee-zhdet-kolledzhiuzbekistana.html

Krueger, A. B., \& Lindahl, M. (2001). Education for growth: Why and for whom? (NBER Working Paper No. 7591). National Bureau of Economic Research https://doi.org/10.3386/w7591

Krueger, D., \& Kumar, K. B. (2004). Skill-specific rather than general education: A reason for US-Europe growth differences? (NBER Working Paper No. 9408). National Bureau of Economic Research. https://doi.org/10.3386/w9408

DTM test natijalari kechikayotganiga izoh berdi [STC comments on the delay of test results publication]. (2019, August 21). Retrieved from https://kun.uz/news/2019/08/21/dtm-test-natijalari-kechikayotganiga-izoh-berdi

Leleur, S. (2007). Systemic planning: Dealing with complexity by a wider approach to planning. Emergence: Complexity \& Organization, 9(1-2), 2-10.

Lipovsky, I. P. (1996). Central Asia: In search of a new political identity. The Middle East Journal, 50(2), 211-223.

MDIS (Singapore) Counselling Sessions. (2019, August 14). Retrieved from http://www.mdis.uz/node/ 733

MHSSE. (2019, March 14). Official Website of the Ministry of Higher and Secondary Specialised Education of the Republic of Uzbekistan. Retrieved from http://www.edu.uz/ru/otm/index

MHSSE. (2018, December 3). O'zbekiston Respublikasi Halq ta'limi vazirligining 2018 2019-o'quv yili uchun asosiy ko'rsatkichlari ¿Key indicators of the Ministry of Public Education of the Republic of Uzbekistan for the 2018-2019 academic year]. Retrieved from https://uzedu.uz/Xtv/BarchasiPage/67? tp =86

Mirziyoyev, S. M. (2019, September 28). Official Address to Teachers and Mentors of Uzbekistan [O'zbekiston o'qituvchi va murabbiylariga bayram tabrigi ]. Retrieved from https://president.uz/uz/lists/view/2881

Moodie, G., \& Wheelahan, L. (2009). The significance of Australian vocational education institutions in opening access to higher education. Higher Education Quarterly, 63(4), 356-370. https://doi.org/10.1111/j.1468-2273.2009.00438.x

Nacional'naja programma po podgotovke kadrov [National Program on Personnel Training]. National Program (Number:463-I) (1997, August 29). Retrieved from http://www.lex.uz/ru/docs/19769

Nilsson, A. (2010). Vocational education and training-an engine for economic growth and a vehicle for social inclusion? International Journal of Training and Development, 14(4), 251-272. https://doi.org/10.1111/j.1468-2419.2010.00357.x

Pjat' krupnyh rossijskih vuzov otkrojut filialy v Uzbekistane [Five major Russian universities will open branches in Uzbekistan]. (2018, February 24). Retrieved from https://nuz.uz/obschestvo/30566-pyat-krupnyh-rossiyskih-vuzov-otkroyut-filialyv-uzbekistane.html

Ob Obrazovanii [On Education]. (1997, August 29). Law of the Republic of Uzbekistan (Number: 464-I). Retrieved from http://www.lex.uz/docs/15622

Ozodlik Radio. (2019, July 9). Abiturient 2019: Priem dokumentov v nekotorye vuzy Uzbekistana vremenno priostanovlen [Applicant 2019: Admission of documents to 
some universities in Uzbekistan is temporarily suspended]. Retrieved from https://rus.ozodlik.org/a/30045127.html

PP-1564, Presidential Decree. (2012, July 4). O prieme v vysshie obrazovatel'nye uchrezhdenija Respubliki Uzbekistan v 2011/2012 uchebnom godu [On admission to higher educational institutions of the Republic of Uzbekistan in the 2011/2012 academic year]. Retrieved from https://www.norma.uz/obrazovanie nauka kultura/o prieme v vysshie obrazova telnye_uchrejdeniya_respubliki_uzbekistan_v_2011_2012_uchebnom_godu

PP-1751, Presidential Decree. (2012, May 7). O prieme v vysshie obrazovatel'nye uchrezhdenija Respubliki Uzbekistan v 2012/2013 uchebnom godu [On admission to higher educational institutions of the Republic of Uzbekistan in the 2012/2013 academic year]. Retrieved from http://www.lex.uz/docs/2010373

PP-1982, Presidential Decree. (2013, June 11). O prieme v vysshie obrazovatel'nye uchrezhdenija Respubliki Uzbekistan v 2013/2014 uchebnom godu [On admission to higher educational institutions of the Republic of Uzbekistan in the 2013/2014 academic year]. Retrieved from https://www.norma.uz/novoe_v_zakonodatelstve/ustanovleny_kvoty_priema_abit urientov_v_vuzy_respubliki

PP-2193, Presidential Decree. (2014, June 26). O prieme v vysshie obrazovatel'nye uchrezhdenija Respubliki Uzbekistan v 2014/2015 uchebnom godu [On admission to higher educational institutions of the Republic of Uzbekistan in the 2014/2015 academic year]. Retrieved from http://lex.uz/docs/2448204

PP-2359, Presidential Decree. (2015, June 23). O prieme v vysshie obrazovatel'nye uchrezhdenija Respubliki Uzbekistan v 2015/2016 uchebnom godu [On admission to higher educational institutions of the Republic of Uzbekistan in the 2015/2016 academic year]. Retrieved from https://nrm.uz/contentf?doc $=406235$ _postanovlenie_prezidenta_respubliki_uzbeki stan ot $23062015 \mathrm{~g} n \mathrm{n} p \mathrm{p}-$ 2359 o prieme $\mathrm{v}$ vysshie obrazovatelnye uchrejdeniya respubliki uzbekistan $\mathrm{v}$ 20152016_uchebnom_godu

PP-2534, Presidential Decree. (2016, May 26). O prieme v vysshie obrazovatel'nye uchrezhdenija Respubliki Uzbekistan v 2016/2017 uchebnom godu [On admission to higher educational institutions of the Republic of Uzbekistan in the 2016/2017 academic year]. Retrieved from https://nrm.uz/contentf?doc $=468052$ kvoty priema po podgotovke bakalavrov v _vysshih_obrazovatelnyh_uchrejdeniyah_respubliki_uzbekistan_na_20162017_uche bnyy_god_(prilojenie_n_1_k_postanovleniyu_prezidenta_ruz_ot_26_05_2016_g_n pp-2534)

PP-2955, Presidential Decree. (2017, May 5). O prieme v vysshie obrazovatel'nye uchrezhdenija Respubliki Uzbekistan v 2017/2018 uchebnom godu [On admission to higher educational institutions of the Republic of Uzbekistan in the 2017/2018 academic year].

PP-4359, Presidential Decree. (2019, June 17). O parametrah gosudarstvennogo zakaza po priemu na uchebu v vysshie obrazovatel'nye uchrezhdenija Respubliki Uzbekistan v 2019/2020 uchebnom godu [On the parameters of the state order for admission to study at higher educational institutions of the Republic of Uzbekistan in the 2019/2020 academic year]. Retrieved from http://lex.uz/docs/4380360 
PP-3504, Presidential Decree. (2018, February 3). O sovershenstvovanii dejatel'nosti Centra srednego special'nogo, professional'nogo obrazovanija Ministerstva vysshego i srednego special'nogo obrazovanija Respubliki Uzbekistan [On enhancement of operations of the Center of Secondary Specialized Professional Education of the Ministry of Higher and Secondary Specialized Education]. Retrieved from https: / / nrm.uz/contentf?doc $=531257$ postanovlenie_prezidenta_respubliki_uzbeki stan ot $0302 \quad 2018 \mathrm{~g}$. $\mathrm{p}$ pp3504_o_sovershenstvovanii_deyatelnosti_centra_srednego_specialnogo_professiona lnogo_obrazovaniya_ministerstva_vysshego_i_srednego_specialnogo_obrazovaniya respubliki uzbekistan\&products $=1$

PP-3769, Presidential Decree. (2018, June 4). O prieme v vysshie obrazovatel'nye uchrezhdenija Respubliki Uzbekistan v 2018/2019 uchebnom godu [On admission to higher educational institutions of the Republic of Uzbekistan in the 2018/2019 academic year]. Retrieved from

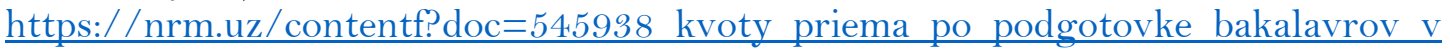
_vysshih obrazovatelnyh uchrejdeniyah respubliki uzbekistan na 20182019 uche bnyy_god_(prilojenie_n_1_k_postanovleniyu_prezidenta_ruz_ot_04_06_2018_g_n_ pp-3769)\&products=1_vse_zakonodatelstvo_uzbekistana

PP-4319, Presidential Decree. (2019, May 14). O dopolnitel'nyh merah po sovershenstvovaniju sistemy priema v vysshie obrazovatel'nye uchrezhdenija na osnove testovyh ispytanij [On additional measures to improve the system of admission to higher educational institutions on the basis of test]. Retrieved from http://www.lex.uz/docs/4334800

PP-5313, Presidential Decree. (2018, January 25). O merah po korennomu sovershenstvovaniju sistemy srednego, srednego special'nogo i professional'nogo obrazovanija [On measures of cardinal improvement of the systems of general secondary, secondary specialized and professional education]. Retrieved from http://www.lex.uz/docs/3523198

PP-57 12, Presidential Decree. (2019, April 29). Ob utverzhdenii Koncepcii razvitija sistemy narodnogo obrazovanija Respubliki Uzbekistan do 2030 goda [On approval of the Concept of development of the public education system of the Republic of Uzbekistan until 2030]. Retrieved from http://lex.uz/docs/4312783

PP-5812, Presidential Decree. (2019, September 6). O dopolnitel'nyh merah po dal'nejshemu sovershenstvovaniju sistemy professional'nogo obrazovanija [On additional measures to further improve the vocational education system $]$. Retrieved from http://lex.uz/ru/docs/4500929

Ranis, G., Stewart, F., \& Ramirez, A. (2000). Economic growth and human development.

World Development, 28(2), 197-219. https://doi.org/10.1016/S0305750X(99)00131-X

Resolution of the Cabinet of Ministers of the Republic of Uzbekistan (Number: 341). (2004, July 20). O Sovershenstvovanii Dejatel'nosti Ministerstva Vysshego i Sregnego Specialnogo Obrazovanija Respubliki Uzbekiostan [Concerning the Activity Modernization of The Ministry of Higher and Secondary Specialized Education of the Republic of Uzbekistan]. Retrieved from https://lex.uz/docs/342902

Ruziev, K., \& Burkhanov, U. (2016). Higher education reforms in Uzbekistan: Expanding vocational education at the expense of higher education? Higher Education in Russia and Beyond, 8(2), 14-15. 
Self, S., \& Grabowski, R. (2004). Does education at all levels cause growth? India, a case study. Economics of Education Review, 23(1), 47-55. https://doi.org/10.1016/So2727757(03)00045-1

SimilarWeb. (2019, September 29). Web traffic data. Retrieved from https://www.similarweb.com

Smolentseva A., Huisman J., \& Froumin I. (2018) Transformation of Higher Education Institutional Landscape in Post-Soviet Countries: From Soviet Model to Where?. In: Huisman J., Smolentseva A., \& Froumin I. (eds) 25 Years of Transformations of Higher Education Systems in Post-Soviet Countries. Palgrave Studies in Global Higher Education. Palgrave Macmillan, Cham. https://doi.org/10.1007/978-3-319-52980$\underline{6 \quad 1}$

Tashpulatov, S., (2012) Systematic approach to improvement of qualification and professional level of pedagogical personnel for secondary specialized professional education. International Conference of upbringing of educated and intellectually advanced generation as the most important condition of sustainable development and modernization of the country, Tashkent.

TESL in Uzbekistan. (2018). Retrieved from https://sites.google.com/view/webstertesl/tesl-in-uzbekistan

V kazhdom rajone stolicy pojavjatsja po chetyre shkoly s 10-11-mi klassami [Four schools with 10-11 grades will appear in each district of the capital]. (2017, June 24). Retrieved from https://kommersant.uz/v-chetyreh-shkolah-kazhdogo-rajonastolitsy-poyavyatsya-10-11-klassy/

V Navoi abiturienty protaranili zabor, chtoby sdat' dokumenty v vuz [In Navoi, applicants rammed a fence to submit documents to a university]. (2019, July 11). Retrieved from https://kun.uz/ru/news/2019/07/13/video-v-navoi-abituriyenty-protaranilizabor-chtoby-sdat-dokumenty-v-vuz

Varela, F. G., Maturana, H. R., \& Uribe, R. (1974). Autopoiesis: the organization of living systems, its characterization and a model. Biosystems, 5(4), 187-196. https://doi.org/10.1016/0303-2647(74)90031-8

Vu, T. B., Hammes, D. L., \& Im, E. I. (2012). Vocational or university education? A new look at their effects on economic growth. Economics Letters, 117(2), 426-428. https://doi.org/10.1016/j.econlet.2012.06.027

Weitz, R. (2018). Uzbekistan's New Foreign Policy: Change and Continuity under New Leadership. Central Asia-Caucasus Institute \& Silk Road Studies Program. https://isdp.eu/content/uploads/2018/01/Richard-WeitzUzbekistan\%E2\%80\%99s-New-Foreign-Policy-Change-and-Continuity.pdf

WIUT. (2018). Orientation Week 2018. Retrieved from http://oldwww.wiut.uz/newswiut/orientation-week-2018

WIUT. (2019). New Updates on Orientation Week 2019. Retrieved from http://oldwww.wiut.uz/news-wiut/orientation-week-2019

World Bank. (2014). Uzbekistan Modernizing Tertiary Education (Report No. 88606-UZ). The World Bank. Retrieved from http://pubdocs.worldbank.org/en/23621 1484721686087/Uzbekistan-HigherEducation-Report-2014-en.pdf 


\begin{abstract}
About the Author
Aleksey Semyonov is a Deputy Rector at TEAM University. He received his MPhil in Psychology and Education from the University of Cambridge, UK in 2010. He obtained both his BSc in Computer Science and PG Certificate in Special Studies in Teaching and Learning from the University of Westminster, UK, in 2005 and 2008, respectively. Aleksey has been awarded a prestigious Hubert H. Humphrey Fulbright fellowship and conducted research and professional development activities at Pennsylvania State University in the United States of America in 2019-2020. His research interests include higher education management, quality assurance and enhancement, curriculum development, and pedagogy. Throughout his career Aleksey has worked in higher education management and administration as well as taken part in various higher education projects involving partners from the United Kingdom, European Union, and the United States of America.
\end{abstract}

